GLOBAL JOURNAL OF EDUCATIONAL RESEARCH VOL 11, NO. 2, 2012: 129-136

COPYRIGHT@ BACHUDO SCIENCE CO. LTD PRINTED IN NIGERIA. ISSN 1596-6224 www.globaljournalseries.com; Info@globaljournalseries.com

\title{
STUDENTS' PREFERENCE OF METHOD OF SOLVING SIMULTANEOUS EQUATIONS
}

UGBODUMA, O. SAMUEL

(Received 14 June 2011; Revision Accepted 19 September 2012)

\begin{abstract}
The study focused on students' preference of two methods of solving simultaneous equations. The researcher adopted three research questions and three hypotheses. The research questions were answered using the descriptive statistics of percentages, while, the hypotheses were tested using the chi-square. The study research design was survey. The total population of SS2 students in Sapele local government area in 2007/2008 Session was 776. Using proportionate stratified random sampling technique to obtained equitable sample size in the three-urban, semi-urban and rural areas. The total sample size used for the study was 458. The instrument for data collection was a Structured Test Questions (STQ) for the SS2 students taught by the researcher. The STQ given to the SS2 students was named Students' Preference of Method Assessment Test Questions (SPMATQ). The SPMATQ was face-validated by eight mathematics teachers. Kudder Richardson - 21 was applied to test the reliability of SPMATQ to obtained $r=0.73$. The findings revealed that SS2 students' preferred substitution method irrespective of their gender for solving simultaneous equations. A recommendation was that students' preference order (substitution method) should be encouraged or followed in teaching and learning of simultaneous equations.
\end{abstract}

KEY WORDS: Preference, Simultaneous, Equations, Substitution, and Elimination

\section{INTRODUCTION}

Preference could mean showing greater interest in or desire for something than something else. This means that students have a particular interest in one method of solving simultaneous equations than other methods. Interest is an important variable in learning because when one becomes interested in an activity, one is likely to be more deeply involved in that activity. Interest is a subjective feeling of concentration or curiosity over something (Harbor-Peters, 1992). Interest is the quality in something that attracts somebody's attention and makes them want to know more about it. It is a thing with which one concerns oneself or about which one is enthusiastic (Hornby, 2003). It is the preference for particular types of activities, that is, tendencies to seek out and participate in certain activities (Agwagah, 1993). It can be expressed through simple statements made by individuals of their likes and dislikes (Imoko and Agwagah, 2006). Preference is the act of preferring, choosing or favouring one above another; that which is chosen or preferred; prior rights; advantage given to one method over others. Students' interest must not be neglected when inculcating knowledge of simultaneous equations. The mathematics teachers who are sole givers of mathematics knowledge must realize that mathematics teaching end-result or success depends on adopted method.

Students' preference can be changed when various methods are used in teaching mathematical concept. Concept is an idea or a principle or proposition (Imoko and Agwagah, 2006). Novak and Godwin (1984) defined a concept as an abstract idea or principle that is

Ugboduma, O. Samuel, Mathematics department; Delta state college of physical education; Mosogar, Delta state, Nigeria 
not limited to one place or time. Method is a particular way of doing something in order to enhance effective behavioural change (Harpercollins, 2001 and Hornby, 2003). Effective behavioural change is the desired effect that makes something different in the way of somebody in order for him to function in a particular situation. This enhances meaningful learning that leads to the development of metacognitive strategies (Cliburn in Imoko and Agwagah, 2006). Novak (1990), meta-cognitive strategies are those strategies that empower the student/learner to learn in a highly meaningful way. Meaningful learning implies achieving a deep understanding of complex ideas that are relevant to students' lives (Jonassen, Peck and Wilson, 1999). Meaningful learning assumes that students or learners already have some knowledge that is relevant to new experiences they encounter and that they are willing to do the mental work necessary to create connections between adopted methods. Geddies and Grosset (2005) see method as the mode or procedure of accomplishing something; orderliness of thought, an orderly arrangement or system; while, methodology is a system of methods or principles for doing something. It is the philosophical analysis of method and procedure employed in classroom interaction. There is need for the mathematics teacher to master the set of methods involved in solving simultaneous equations to enable students apply them accordingly.

Good methodologies in teaching stimulate students' and promote proper understanding of simultaneous equations. The key factor for changing students' preference in a mathematics concepts teaching and learning is carefully designed good methods adopted by the adept mathematics teacher (Ugboduma, 2006). Nigerians need mathematics teachers who are adept at imparting mathematical knowledge on students using good methodology. No wonder, the National Policy on Education (FRN) (2004), states that mathematics teaching in primary and secondary schools shall be by practical, exploratory and experimental methods. This will encourage, sustain and motivate students' interest towards learning. Learning is a relatively permanent change in behaviour as a result of experience (Mallum and Haggai, 2004). The most glaring thing that occurs when learning has taken place is change. That is, change in the behaviour of the individual student.

A linear equation in two variables has an infinite number of solutions. Anyone of the infinite number of $x$-values can be substituted into an equation and each one has a corresponding $y$-value. However, for two such equations, there may be just one pair of $x$ and $y$ - values that satisfy both equations simultaneously. Jaggi (2006) defined an equation as a statement of equality. If the equality (being equal) is true only for certain values of the unknown qualities involved in the equation, then, it is called conditional equation and the = sign is used. If the equality is true for all values of the unknown qualities involved, the equation is called an identity (equivalence) and $\equiv$ sign is used. Geddies and Grosset (2005), described equation as an act of equaling; the state of being equal; a usually formal statement of equivalence (as in logical and mathematical expressions) with the relations denoted by the sign $=\cdot$ Equation is a mathematical statement showing that two amounts or values are the same. For example, 6 $x 4=12 \times 2$ and $2 x+y=54$. Simultaneous is two events done, happening or occurring at the same time (Geddies and Grosset, 2005; Harpercollins, 2001 and Hornby, 2003). Simultaneous equations are two or more equations that are true at one end, and are therefore satisfied by the same values of the unknowns involved. For example, the equations $2 x+y=3$ and $3 x+4 y=2$ are simultaneous equations having solution of $x=2$ and $y=-1$.

The progress of any student depends largely on the kind of mathematics teachers that form and instruct him mathematically. Okafor (2004) sees the mathematics teacher as class chief executive who supervises students during class instruction by applying various methods in teaching concept. This is mathematics goals achievement. Understanding is the gene that kills discouragement in students. Many students in school see simultaneous equations problems or questions as demanding and difficult involving numerous processes to solutions (products). They either stop attempting it in examinations or study personally to build interest. They term simultaneous equations is vigorous and heterogeneous, detrimental to heuristic (ugboduma, 2006). Heuristic is what is needed to arrest this trend. Hence, this paper sets to examine two methods [solution by substitution 
and solution by equating coefficient (elimination)] for solving simultaneous equations and determine the one student's prefer in schools.

\section{Statement of the problem}

Ineffective method of solving simultaneous equations by secondary school students had threatened the very essence of good academic performance in West African Senior School Certificate Examination (WASSCE). A common noticeable problem among mathematics students' is lack of effective method of solving simultaneous equations. This has resulted to students showing negative attitude, loss of interest and lack of attention in class during simultaneous equations instructions leading to examination malpractices. These practices must be discouraged by the mathematics teachers adopted method of solving simultaneous equations through mastery the set of methods (elimination and substitution) involved in solving simultaneous equations to enable students apply them accordingly. From these two methods adapted by the mathematics teachers, which one do the students' preferred in solving simultaneous equations to enhance meaningful learning in Sapele local government area of Delta state? Hence, this study seeks to investigate the two methods [solution by substitution and solution by equating coefficient (elimination)] for solving simultaneous equations and determine the one student's prefer in schools.

\section{Purpose of the study}

The purpose of the study was to:

1. examine the proportion of senior secondary II students (SSS2) in Sapele Local Government who showed preference for one method of solving simultaneous equations.

2. find out whether sex differences influence SSS2 students preference for method of solving simultaneous equations.

3. determine whether urbanization and ruralization factor influence SSS2 students preference for method solving simultaneous equations.

\section{Significance of the study}

The results of this study will help to improve the teaching and learning of simultaneous equations by adopting the two methods (substitution and elimination). The study will be of great benefits to mathematics curriculum developers, mathematics teachers, and students' on how students' level of learning simultaneous equations can be improved viz methods of solving them.

The mathematics curriculum developers would benefit a lot from the outcome of this study because it will serve as research based (eye opener) in developing comprehensive secondary school mathematics simultaneous equations curriculum and methods of providing solutions in line with students' preference. The outcome of this study may also assist mathematics curriculum developers on how best to counsel mathematics teachers' through the measures of students preference order in order to predict their performance in simultaneous equations teaching. The mathematics teachers will benefit from the result of this study on how to use the methods of solving simultaneous equations to simulate students' interest in classroom interactions. With these, students' will be help to contribute and improve the ways they study by exploiting powers of the adapted methods of providing solutions to simultaneous equations to enhance good performance. More so, they will be reposition in order to solve other mathematical problems involving applications of simultaneous equations methods of solutions.

\section{Research questions}

The following research questions were asked:

i what proportion of SSS2 students showed preference for one type of method of solving simultaneous equations?

ii what proportion of male and female SSS2 students showed preference for one method of solving simultaneous equations?

iii what proportion of urban and rural SSS2 students showed preference for one method of solving simultaneous equations?

\section{Hypotheses}

The following hypotheses were postulated for the study: 
$H_{1}$ : SSS2 students have no preference for any method of solving simultaneous equations.

$\mathrm{Ho}_{2}$ : there is no gender barrier in SSS2 students' preference of method of solving simultaneous equations.

$\mathrm{Ho}_{3}$ : schools locations have no effect on SSS2 students' preference of method of solving simultaneous equations.

\section{Methods}

The study was a survey research design. The reason for adopting this design is because it consisted of group of people and data collected are analyzed from few people who are considered to be representative of the entire group (Nworgu, 2006) and successful researchers employed it in related studies (Dosunmu, 2006; Kosemani, 2006).The study covered SSS2 students of eight (8) out of the fourteen (14) public secondary schools in Sapele Local Government Area of Delta State. The total population of SSS2 students in the fourteen (14) public secondary schools in the Sapele Local Government of Delta State in 2007/2008 academic session was 776 from two (2) single girls' schools, two (2) single boys schools and ten (10) co-educational schools respectively. The proportionate stratified random sampling technique was used to have equitable sample size. The fourteen (14) secondary schools were divided into three segments - urban, semi-urban and rural by the researcher. The urban consisted of eight (8) secondary schools with four (4) schools selected; three (3) semi-urban schools with two (2) schools selected; and three (3) rural schools with two (2) selected. The researcher believes that these eight (8) secondary schools selected is a true representation of the population. The sample population used before the proportion was 776 SSS2 students.
The proportion of the sample to the population known as sampling fraction is determined as $458 / 776=0.59(59 \%)$. The sample size for each segment was computed as: Urban segment $=0.59 \times 474=280$; Semi-urban $=0.59 x$ $239=141$ and Rural segment $=0.59 \times 63=$ 37. Total sample size of SSS2 used was 458 . The instrument for data collection was a Structured Test Questions (STQ) for the SSS2 students taught by the researcher using the two methods (elimination and substitution) adopted in solving simultaneous equations. The example used for the students was $3 x+2 y=16$ and $4 x-3 y=10$ for fifteen minutes each (30 minutes) for the two methods adopted. The Structured Test Questions (STQ) given to the SSS2 students was named Students' Preference of Method Assessment Test Questions (SPMATQ). The SPMATQ was face-validated by eight (8) mathematics teachers of the schools selected whether it is in line with simultaneous equations mathematics syllabus. The suggestions given were used in producing the final SPMATQ for the study. The KudderRichardson (K-R) 21 was applied to test the reliability of the SPMATQ (Nworgu, 2006). The reason for adopting Kudder-Richardson (K-R) 21 is the dichotomous nature (elimination and substitution) methods for solving simultaneous equations. It was administered to eighty (80) SSS2 mathematics students of both sexes in a school that did not participate in the main study. A reliability co-efficient of $r=0.73$ was obtained and by implication, the instrument was reliable. The assessment question was: Solve $5 x+2 y=14$ and $3 x-4 y=24 ; x+y=36$ and $x-2 y=6$ using any method of choice from the two adopted in the example above. The reason is to determine area of their preference in method. The SPMATQ work solution was collected after thirty (30) minutes and analyzed. The research questions were subjected to descriptive statistics of percentages; while, the hypotheses were tested using chisquare statistics. 


\section{RESULTS AND DISCUSSIONS}

Research question 1: What proportion of SSS2 students showed preference for one type of method of solving simultaneous equation?

Table 1: Proportion of SSS2 students that showed preference for one type of method

\begin{tabular}{|l|l|ccc|c|}
\hline Locations & Gender & \multicolumn{2}{|c|}{ Preference proportion of method } & Total \\
& & Elimination & Substitution & \\
\hline Urban & Males = 149 & $68(76 \%)$ & $81(43 \%)$ & 149 \\
& Females=131 & $22(24 \%)$ & $109(57 \%)$ & 131 \\
& & $90(32 \%)$ & $190(68 \%)$ & $280(100 \%)$ \\
\hline Semi-urban & Males =77 & $39(57 \%)$ & $38(53 \%)$ & 77 \\
& Females =64 & $30(43 \%)$ & $34(47 \%)$ & 64 \\
& & $69(49 \%)$ & $72(51 \%)$ & $141(100 \%)$ \\
\hline Rural & Males = 20 & $08(50 \%)$ & $12(57 \%)$ & 20 \\
& Females = 17 & $08(50 \%)$ & $09(43 \%)$ & 17 \\
& & $16(43 \%)$ & $21(57 \%)$ & $37(100 \%)$ \\
\hline Total & Gender & $175(38 \%)$ & $283(62 \%)$ & $458(100 \%)$ \\
\hline
\end{tabular}

Table1above, showed that 190(68\%) SSS2 students preferred substitution method, while, 90 (32\%) preferred elimination method in urban secondary schools in Sapele local government area of Delta state. 69(49\%) SSS2 students preferred elimination method, while, $72(51 \%)$ preferred substitution method in semi- urban location. In rural area, 16 (43\%) and 21 (57\%) SSS2 students preferred elimination and substitution methods respectively. In gender, 283(62\%) SSS2 students in proportion preferred substitution method of solving simultaneous equations to elimination method with $175(38 \%)$ in proportion having preference difference of $108(24 \%)$.

Hypothesis 1: SSS 2 students have no preference on any method of solving simultaneous equations

Table 2: Chi-square analysis of SSS2 students' preference of method of solving simultaneous equation

\begin{tabular}{|l|c|c|}
\hline Locations & $\begin{array}{c}\text { SSS2 Students } \\
\text { (observed frequency) }\end{array}$ & $\begin{array}{c}\text { SSS2 Students } \\
\text { (expected frequency) }\end{array}$ \\
\hline Urban & 280 & 152.67 \\
\hline Semi-urban & 141 & 152.67 \\
\hline Rural & 37 & 152.67 \\
\hline Total & 458 & 458 \\
\hline
\end{tabular}

$$
\begin{aligned}
& =106.20+0.8920+87.64 \\
& =\quad 194.73: \mathrm{X}^{2} \text { critical }=\mathrm{X}^{2}{ }_{2,0.05}=5.99
\end{aligned}
$$

Since $X^{2}$ critical is less than $X^{2}$ calculated, the null hypothesis of no preference in method is not accepted. This implies that SSS2 students have preference on method of solving simultaneous equations.

Research question 2: What proportion of males and females SSS2 students' showed preference for one method of solving simultaneous equations? 
Table 3: Proportion of males and females SSS2 students' preference for one method

\begin{tabular}{|c|c|c|c|}
\hline Locations & Gender & $\begin{array}{l}\text { Preference proportion of method } \\
\text { Elimination } \quad \text { Substitution }\end{array}$ & Total \\
\hline Urban & $\begin{array}{l}\text { Males }=149 \\
\text { Females }=131\end{array}$ & $\begin{array}{r}81(43 \%) \\
109(57 \%)\end{array}$ & $\begin{array}{l}149(53 \%) \\
131(47 \%)\end{array}$ \\
\hline Semi-urban & $\begin{array}{l}\text { Males }=77 \\
\text { Females }=64\end{array}$ & $\begin{array}{l}39(57 \%) \\
30(43 \%)\end{array}$ & $\begin{array}{l}77(55 \%) \\
64(45 \%)\end{array}$ \\
\hline Rural & $\begin{array}{ll}\text { Males } & =20 \\
\text { Females } & =17\end{array}$ & $\begin{array}{l}08(50 \%) \\
08(50 \%)\end{array}$ & $\begin{array}{l}20(54 \%) \\
17(46 \%)\end{array}$ \\
\hline
\end{tabular}

Table 3, revealed that 115 males with average percentage of 61 , and 60 females with average percentage of 39 preferred elimination method of solving simultaneous equations. The result also showed that 131 males and 152 females with average percentages of 51 and 49 respectively preferred substitution method of solving simultaneous equations in Sapele local government area of Delta state. From the above, it implies that male SSS2 students' preferred substitution method of solving simultaneous equations to their female counterparts in Sapele senior secondary schools.

Hypothesis 2: There is no gender barrier on SSS2 students' preference of method of solving simultaneous equations

Table 4: Chi-square analysis of gender barrier on SSS2 students' preference of method of solving simultaneous equations

\begin{tabular}{|l|l|l|l|}
\hline Locations & Males & Females & Total \\
\hline Urban & $149(150.39)$ & $131(129.61)$ & 280 \\
\hline $\begin{array}{l}\text { Semi- } \\
\text { urban }\end{array}$ & $77(75.73)$ & $64(65.27)$ & 141 \\
\hline Rural & $20(19.87)$ & $17(17.13)$ & 37 \\
\hline Total & $246(53.71)$ & $212(46.29)$ & 458 \\
\hline
\end{tabular}

$$
\begin{aligned}
& X^{2}=\frac{(149-150.39)^{2}}{150.39}+\frac{(131-129.61)^{2}}{129.61}+\frac{(77-75.73)^{2}}{75.73}+\frac{(64-65.27)^{2}}{65.27}+\frac{(20-19.87)^{2}}{19.87}+\frac{(17-17.13)^{2}}{17.13} \\
& =0.01285+0.01491+0.02130+0.02471+0.00085+0.00099=0.07561 \\
& X_{2,0.05}^{2}=-X^{2}-\text { critical }=5.99>X^{2}-\text { cal }=0.076
\end{aligned}
$$

The calculated value is less than the critical value; hence, the null hypothesis is accepted. This implies that gender have no barrier on SSS2 students preference of method of solving simultaneous equations; but, male SSS2 students' 246(53.71) preferred one method of solving simultaneous equations to their female counterparts $212(46.29)$ in Sapele senior secondary schools. This result is in agreement with research question 2 answered above, that male SSS2 students' with 131(51\%) preferred substitution method of solving simultaneous equations to their female counterparts with $152(49 \%)$ in Sapele senior secondary schools. 
Research question 3: What proportion of urbanized and ruralized SSS2 students showed preference for one method of solving simultaneous equations?

Table 5: Proportion of urbanized and ruralized SSS2 preference method

\begin{tabular}{|l|l|lc|l|}
\hline Locations & Gender & \multicolumn{2}{|c|}{ Preference proportion of method } & Total \\
& & Elimination & Substitution & \\
\hline Urbanized & Males =226 & $107(67 \%)$ & $119(45 \%)$ & 226 \\
(urban \& semi-urban) & Females=195 & $52(33 \%)$ & $143(55 \%)$ & 195 \\
\hline Ruralized & Males =20 & $08(50 \%)$ & $12(57 \%)$ & 20 \\
& Females=17 & $08(50 \%)$ & $09(43 \%)$ & 17 \\
\hline
\end{tabular}

From table 5 above, 159 urbanized and 16 ruralized SSS2 students preferred elimination method, while, 262 urbanized and 21 ruralized SSS2 students preferred substitution method in solving simultaneous equations in Sapele local government area of Delta state.

Hypothesis 3: Schools' locations have no effect on SSS2 students' preference of method of solving simultaneous equations

Table 6: Chi-square analysis of schools' locations effect on SSS2 students' preference method of solving simultaneous equations

\begin{tabular}{|l|c|c|}
\hline Locations & $\begin{array}{l}\text { SSS2 students } \\
\text { (observed frequency) }\end{array}$ & $\begin{array}{l}\text { SSS2 students } \\
\text { (expected frequency) }\end{array}$ \\
\hline Urbanized & 421 & 229 \\
\hline Ruralized & 37 & 229 \\
\hline
\end{tabular}

$$
\begin{aligned}
& X^{2}=\frac{(421-229)^{2}}{229}+\frac{(37-229)^{2}}{229} \\
& =160.98+160.98 \\
& =321.98 \\
& X^{2}{ }_{1,0.05} \text {-critical }=3.84
\end{aligned}
$$

Since the chi-square critical value is < than calculated value, the null hypothesis is not accepted. This means that schools' locations have effect on SSS2 students' preference of method of solving simultaneous equations in Sapele local government area of Delta state.

Finally, the results of tables 1-6 showed that SSS2 students' preferred substitution method of solving simultaneous equations both in urban and rural areas of Sapele local government area. The results also revealed that male SSS2 students in Sapele local government senior secondary schools preferred substitution method to their female students' irrespective of the locations. All these are in agreement with West Africa Examination Council (WAEC) syllabus that "SSS classes' students should be taught simultaneous equations in mathematics using the substitution method as compulsory". The findings of this study does not rule out the application of elimination method in teaching and learning of simultaneous equations in secondary schools because elimination method is preferred to be use in coefficient that involved more than one and vice versa.

Conclusively, based on the findings, the mathematics teachers should strictly apply substitution method in teaching and learning of simultaneous equations because students preferred it to elimination method in Sapele local government area of Delta state. This will make students' develop high interest towards other mathematical concepts learning. Their curiosity also will be motivated in solving header 
simultaneous equations concepts. It is therefore recommended that students' should be encouraged to adopt substitution method in solving simultaneous equations in schools. Also, SSS classes' mathematics teachers should acquired the basic knowledge of substitution method of solving simultaneous equations in schools.

\section{REFERENCES}

Agwagah, U. N. V., 1993. Instruction in mathematics reading as a factor in students' achievement and interest in word problem solving. Unpublished Ph.D thesis, Nsukka: University of Nigeria.

Dosunmu, S., 2006. Teachers' apathy to social reproduction: A stop-gap in national development. Journal of national association of science, humanities and education research, 4(1): 12-19.

Federal Republic of Nigeria (FRN), 2004. National policy on education ( $4^{\text {th }}$ Edition). Lagos: National Educational Research Development Commission (NERDC), 1415.

Geddies and Grosset., 2005. Webster's universal dictionary and thesaurus (Reprinted Edition) Poland: Ozgraf, S.A. 176, 438.

Harbor-Peters, V. F., 1992. Aspects of further mathematics that present difficulties to graduating senior secondary students. Journal of mathematics association of Nigeria, 22(1):74-78.

Harpercollins, 2001. Collins cobuild English dictionary for advanced learners $\left(3^{\text {rd }}\right.$ Edition). Spain: Mateu Cromo Artes Graficas, S.A. 518, 1452.

Hornby, A. S., 2003. Oxford advanced learners' dictionary of current english $\left(5^{\text {th }}\right.$ Impression). New York: Oxford University Press, 391, 1105.
Imoko, B. I. and Agwagah, U. N. V., 2006. Improving students' interest in mathematics through the concept mapping technique: A focus on gender. Journal of research in curriculum and teaching, 1(1): 30-38.

Jaggi, V. P., 2006. Dictionary of mathematics ( $1^{\text {st }}$ Edition). Nigeria: Educational printing and publishing, 92, 222.

Jonassen, H. D., Peck, S. and Wilson, B. G., 1999. Learning with technology. Upper saddle river, $\mathrm{NJ}$ : Morrill publishing.

Kosemani, I. C., 2006. Reading interest and preferences of the male and female senior secondary school students: Need for re-orientation. Journal of research development, 7(2): 6-11.

Mallum, J. and Haggai, M., 2004. Educational psychology: Classroom practice. Jos: YaByangs publishers.

Novak, J. D. and Godwin, B. D., 1984. Learning how to learn. New York: Cambridge University Press.

Novak, J. D., 1990. Concept maps and vee diagrams: Two meta-cognitive tools to facilitate meaning. Instructional science, 19(1): 29-52.

Nworgu, B. G., 2006. Educational research: Basic issues and methodology $\left(2^{\text {nd }}\right.$ Edition). Nsukka: University trust publishers.

Okafor, I., 2004. Teacher education and recurrent training. In A.O.K.Noah; D.O. Shonibare; A. A. Ojo and I.Olujuwon (Eds.).Curriculum implementation and professionalizing teaching in Nigeria.

Ugboduma, S. O., 2006. Effective methods of teaching mathematics as it affects Nigerian secondary schools. Journal of knowledge review, 12(1):118-124. 